\title{
ULASAN ARTIKEL ILMIAH METODE AUDIT TI
}

Disusun Untuk Memenuhi Tugas Ujian Tengah Semester

Matakuliah Audit Teknologi Informasi

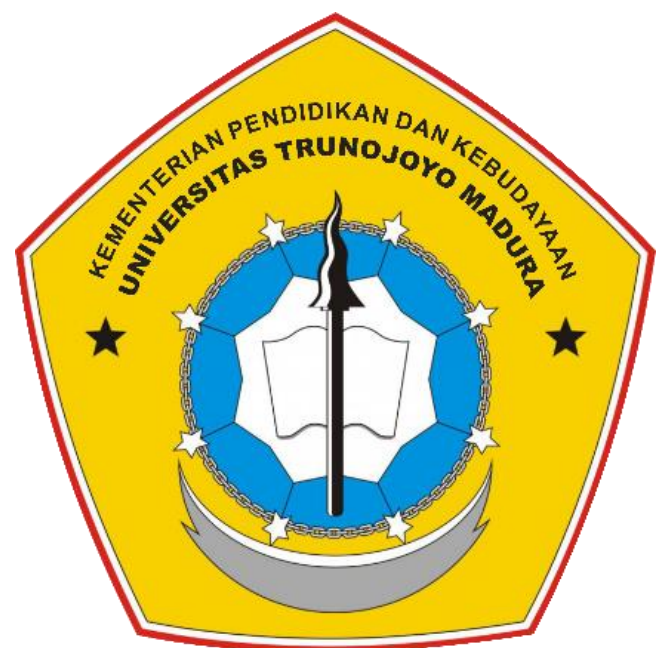

Disusun Oleh:

Abdur Rouf

170441100037

Dosen Pengampu: Shofia Hardi, S.Kom., M.T.

PROGRAM STUDI S1 SISTEM INFORMASI

JURUSAN TEKNIK INFORMATIKA

FAKULTAS TEKNIK

UNIVERSITAS TRUNOJOYO MADURA

2020 


\title{
ULASAN ARTIKEL ILMIAH METODE AUDIT TI
}

\author{
Abdur Rouf \\ Program Studi Sistem Informasi, Universitas Trunojoyo Madura \\ E-Mail: 170441100037@student.trunojoyo.ac.id
}

\begin{abstract}
Abstrak
Perusahaan semakin meningkatkan kinerja TI untuk mendorong pertumbuhan bisnis, mendapatkan keunggulan kompetitif, dan memungkinkan diferensiasi strategis, manajemen dan tata kelola TI. Kondisi tersebut semakin penting karena semakin kompleksnya organisasi bisnis serta sistem dan teknologi. Audit teknologi informasi membutuhkan kerangka kerja yang didasarkan pada prinsip dan persyaratan akuntabilitas yang mendorong perilaku yang diinginkan dalam penerapan dan penggunaan teknologi. Dalam laporan ini, kami mengulas beberapa penerapan metode audit teknologi informasi yaitu ISACA, COBIT 5, COSO, ITIL v.3, IIA, dan ISO/IEC 27000 sebagai panduan dengan standarisasi yang diakui internasional untuk proses audit tata kelola perusahaan teknologi informasi dan komunikasi. Pada ulasan yang telah kita lakukan kali ini memberikan informasi baru dan wawasan mengenai tahapan-tahapan yang ada dari beberapa penerapan kerangka kerja audit teknologi informasi yang terstandarisasi dan diakui oleh internasional. Dengan adanya audit TI yang baik, maka diharapkan perusahaan dapat meningkatkan nilai kinerja dan produktifitas perusahaan serta dapat memprediksi risiko-risiko yang mungkin saja bisa muncul.
\end{abstract}

Kata Kunci: Audit, COBIT, COSO, ITIL v.3, IIA 


\section{PENDAHULUAN}

Perusahaan semakin meningkatkan kinerja teknologi informasi dalam meningkatkan pertumbuhan bisnis, mendapatkan keunggulan kompetitif, dan memungkinkan diferensiasi strategis, manajemen dan tata kelola TI. Kondisi tersebut semakin penting karena semakin kompleksnya organisasi bisnis serta sistem dan teknologi. Dalam skenario yang sedemikian kompleks, salah satu tantangan terbesar bagi organisasi TI adalah perlindungan aset informasi, pencegahan pencurian kekayaan intelektual, dan menjaga privasi karyawan dan pelanggan.

Audit teknologi informasi membutuhkan kerangka kerja yang didasarkan pada prinsip dan persyaratan akuntabilitas yang mendorong perilaku yang diinginkan dalam penerapan dan penggunaan teknologi. Ini melibatkan adanya kerangka kerja audit TI yang mendukung struktur dan proses manajemen untuk memberikan jaminan bahwa strategi bisnis diselaraskan dengan dan mendukung tujuan bisnis, konsisten dengan hukum dan peraturan melalui kepatuhan terhadap kebijakan dan kontrol internal, memberikan penugasan tanggung jawab kepada semua untuk mengelola risiko.

Dalam laporan ini, kami mengulas beberapa penerapan metode audit teknologi informasi yaitu ISACA, COBIT 5, COSO, ITIL v.3, IIA, dan ISO/IEC 27000 sebagai panduan dengan standarisasi yang diakui internasional untuk proses audit tata kelola perusahaan teknologi informasi dan komunikasi. Hal tersebut bertujuan untuk menunjukkan bagaimana audit tata kelola TI dapat dicapai dengan menggunakan prinsip-prinsip pada masing-masing metode yang dipilih.

\section{KAJIAN PUSTAKA}

\subsection{Audit Teknologi Informasi}

Audit teknologi informasi adalah suatu kegiatan yang dilakukan untuk mengawasi serta mengendalikan sebuah infrastruktur teknologi informasi di segala aspek secara menyeluruh. Tujuan dari adanya Audit Teknologi Informasi yaitu untuk mengevaluasi proses penerapan TI di sektor sistem internal agar dapat menambah nilai manfaat dan mengurangi 
risiko kerusakan. Aspek audit dalam sistem informasi sangat berkaitan dengan proses pemeriksaan sistem informasi pada tahapan input, pengolahan, dan output.

\subsection{ISACA}

ISACA adalah asosiasi global yang membantu individu dan perusahaan mencapai potensi positif dari teknologi. ISACA pertama kali berdiri pada tahun 1969 dan bertahan hingga saat ini. ISACA memanfaatkan keahlian 460.000 profesional yang terlibat dalam informasi dan keamanan siber, tata kelola, jaminan, risiko dan inovasi, serta anak perusahaan kinerja perusahaannya, CMMI Lembaga, untuk membantu memajukan inovasi melalui teknologi. ISACA hadir di 188 negara, termasuk lebih dari 220 bab di seluruh dunia dan kantor di Amerika Serikat dan Cina.

\subsection{COBIT}

COBIT 5 atau Control Objektives For Information and Related Technology merupakan kerangka kerja audit TI terbaru dari panduan yang dikembangkan dan diperkenalkan oleh ISACA dan dibuat berdasarkan pengalaman selama menggunakan COBIT terdahulu dalam kurun waktu lebih dari 15 tahun di banyak organisasi perusahaan dan penerapan metode pada bidang bisnis, komunitas, IT, risiko, asuransi, dan keamanan. COBIT 5 memberikan definisi dan penjelasan dengan detail di sejumlah audit tata kelola teknologi informasi dan kegiatan manajemen proses. COBIT 5 menyediakan paket kerangka kerja terpadu yang komprehensif dan memberikan bantuan terhadap perusahaan dalam mewujudkan tujuan bisnis mereka dalam kaitannya dengan audit tata kelola TI dan pengelolaan aset informasi di perusahaan. COBIT 5 akan membantu perusahaan dalam mengoptimalkan nilai perusahaan serta menjaga keseimbangan dalam memperoleh keuntungan dan mengurangi besaran tingkat risiko dalam pemanfaatan sumber daya. 


\subsection{COSO}

Committee of Sponsoring Organisations of the Treadway

Commission yaitu salah satu panduan kerangka kerja dalam audit teknologi informasi yang diperkenalkan pertama kali pada tahun 1992 sebagai standar operasional prosedur untuk menjalankan proses kontrol pelaksanaan TI yang baik sehingga perusahaan dapat mewujudkan tujuan bisnis mereka dengan mengurangi adanya risiko kegagalan yang mungkin terjadi. COSO memberikan pembagian kategori level entitas menjadi suatu operasi, finansial, pelaporan dan kepatuhan. Paket kerangka kerja ini memiliki cakupan lebih dari 20 prinsip level dasar yang berguna untuk menggantikan konsep awal yang berhubungan dengan elemen: pengendalian lingkungan, penilaian risiko, pengendalian aktivitas, informasi dan komunikasi serta proses pemantuan.

\subsection{ITIL}

Information Technology Infrastructure Library yaitu metode kerja yang banyak dipergunakan untuk pengelolaan layanan teknologi informasi organisasi perusahaan yang memiliki fokus pada proses kegiatan menyelaraskan layanan TI dengan yang menjadi kebutuhan bisnis perusahaan. ITIL akan memberikan gambaran bagaimana suatu urutan prosedur, penugasan dan daftar pemeriksaan yang dapat diimplementasikan oleh sebuah organisasi perusahaan tertetntu untuk membangun hubungan tujuan bisnis perusahaan dengan strategi bisnisnya. COSO memberikan nilai, dan mempertahankan tingkat minimum kompetensi. Hal ini akan membuat organisasi perusahaan untuk mengambil ketetapan data dasar yang dapat melakukan perencanaan, proses pelaksanaan, dan pengukuran. Hal ini berguna untuk menunjukkan kepatuhan dan untuk menentukan nilai peningkatan kinerja TI.

\subsection{IIA}

The Institute of Internal Auditor merupakan sebuah wadah perkumpulan profesi ahli dalam bidang audit internal yang lebih sering 
dikenal sebagai advokat, pengajar, dan penyedia panduan standar, pedoman kerangka kerja yang jelas, dan proses sertifikasi. Di tahun 2008 IIA menerbitkan panduan standar dalam proses audit internal yang terbaru dan akan memperluas cakupan ruang lingkup suatu pekerjaan dengan memberikan nilai atribut-atribut, kinerja perusahaan dan langkah implementasi. Paket kerangka kerja audit TI ini mensyaratkan seorang auditor internal untuk melakukan proses audit sesuai dengan kriteria yang diterima. Untuk praktik profesional ketika kegiatan audit internal mengevaluasi dan berkontribusi pada peningkatan manajemen risiko, pengendalian dan tata kelola menggunakan pendekatan yang sistematis dan disiplin.

\subsection{ISO/IEC 27000}

International Organization for Standardization merupakan sebuah asosiasi organisasi internasional independen dari non-pemerintahan untuk standarisasi suatu barang. Internasional Electrotechnical Commission merupakan sebuah asosiasi oraganisasi dalam proses standarisasi barang tertentu secara internasional yang memberikan persiapan dan publikasi yang memiliki kualifikasi di semua bidang teknologi elektrik, elektronika dan teknologi lain yang terkait. Paket kerangka kerja standar ini digunakan untuk memberi dukungan inovasi dan memberikan sebuah solusi untuk tantangan global. Seri ISO/IEC 27000 merupakan kerangka kerja terbaru sebagai pengganti dari ISO 17799.

Seri ISO/IEC 27000 terdiri dari:
a. ISO/IEC 27000:2009 - ISMS Overview and Vocabulary
b. ISO/IEC 27001:2005 - ISMS Requirements
c. ISO/IEC 27002:2005 - Code of Practice for ISMS
d. ISO/IEC 27003:2010 - ISMS Implementation Guidance
e. ISO/IEC 27004:2009 - ISMS Measurements
f. ISO/IEC 27005:2008 - Information Security Risk Management
g. ISO/IEC 27006:2007 - ISMS Certification Body Requirements
h. ISO/IEC 27007 - Guidelines for ISMS Auditing 


\section{METODE PENELITIAN}

Dalam laporan ini memanfaatkan adanya metode studi literatur yang digunakan untuk pembelajaran dan pemahaman informasi yang terkait dengan pokok pembahasan metode audit teknologi informasi. Literatur yang digunakan dalam pembahasan ini didapatkan dari berbagai sumber seperti literatur digital, dan artikel jurnal penelitian. Langkah metode pengumpulan data dari dalam laporan ini diperoleh melalui observasi dan pembahasan analisis terhadap implementasi metode audit teknologi informasi yang sudah ada sebelumnya. Analisis ini nantinya dapat diperoleh data-data yang memiliki relevansi pada topik review yang dilakukan.

\section{PEMBAHASAN}

\subsection{Hasil Review Artikel}

Berikut ini tabel ringkasan hasil ulasan dari beberapa artikel ilmiah terkait metode dalam audit teknologi informasi:

Tabel 4.1 Ringkasan Review Artikel

\begin{tabular}{|c|c|c|c|c|}
\hline No. & $\begin{array}{c}\text { Pengarang, } \\
\text { Tahun, } \\
\text { Sumber }\end{array}$ & Objek & Metode & Hasil \\
\hline 1. & $\begin{array}{l}\text { Naufal Labib, } \\
2019, \\
\text { OSF } \\
\text { PREPRINTS }\end{array}$ & $\begin{array}{l}\text { Layanan yang } \\
\text { disediakan } \\
\text { oleh ISACA. }\end{array}$ & ISACA & $\begin{array}{l}\text { ISACA melakukan } \\
\text { pembekalan secara } \\
\text { profesional kepada } \\
\text { auditor TI dengan } \\
\text { pengetahuan, } \\
\text { pelatihan, } \\
\text { pendidikan dan } \\
\text { komunitas dalam } \\
\text { beralih untuk } \\
\text { memajukan karier } \\
\text { dan memberi } \\
\text { perubahan } \\
\text { organisasi mereka } \\
{[1] \text {. }}\end{array}$ \\
\hline 2. & $\begin{array}{l}\text { Ryan Randy } \\
\text { Suryono, Dedi } \\
\text { Darwis, dan } \\
\text { Surya Indra } \\
\text { Gunawan, } \\
2018,\end{array}$ & $\begin{array}{l}\text { Tingkat } \\
\text { kematangan } \\
\text { pengendalian } \\
\text { proses } \\
\text { teknologi } \\
\text { informasi di }\end{array}$ & COBIT 5 & $\begin{array}{l}\text { Beberapa } \\
\text { kelemahan yang } \\
\text { paling fatal adalah } \\
\text { lembaga belum } \\
\text { membuat suatu } \\
\text { prosedur langkah- }\end{array}$ \\
\hline
\end{tabular}




\begin{tabular}{|c|c|c|c|c|}
\hline & $\begin{array}{l}\text { Jurnal } \\
\text { TEKNOINFO }\end{array}$ & $\begin{array}{l}\text { suatu } \\
\text { lembaga. }\end{array}$ & & $\begin{array}{l}\text { langkah yang baku } \\
\text { di dalam kegiatan } \\
\text { pengamanan data } \\
\text { dan informasi, } \\
\text { sehingga perlunya } \\
\text { rekomendasi untuk } \\
\text { mencapai tujuan } \\
\text { yang diharapkan } \\
\text { [2]. }\end{array}$ \\
\hline 3. & $\begin{array}{l}\text { Adie } \\
\text { Pamungkas, } \\
2017, \\
\text { Jurnal } \\
\text { Akuntansi } \\
\text { Maranatha }\end{array}$ & $\begin{array}{l}\text { Enterprise } \\
\text { Risk } \\
\text { Management } \\
\text { pada } \\
\text { perusahaan } \\
\text { manufaktur. }\end{array}$ & $\mathrm{COSO}$ & $\begin{array}{l}\text { penerapan } \\
\text { enterprise risk } \\
\text { management } \\
\text { (COSO) } \\
\text { padaperusahaan } \\
\text { manufaktur di } \\
\text { Indonesia sudah } \\
\text { efisien, terbukti } \\
\text { dengan hasil olah } \\
\text { statistic yang } \\
\text { menunjukan rata- } \\
\text { rata penerapannya } \\
\text { sudah mencapai } \\
\text { angka 78\%. Nilai } \\
\text { perusahaannya pun } \\
\text { dalam kondisi } \\
\text { yang baik dimana } \\
\text { nilai rata-ratanya } \\
62,3 \% \text { [3]. }\end{array}$ \\
\hline 4. & $\begin{array}{l}\text { Ari Putra } \\
\text { Wijaya, Putu } \\
\text { Widiadnyana, } \\
\text { Ida Bagus Alit } \\
\text { Swamardika, } \\
2016, \\
\text { International } \\
\text { Journal of } \\
\text { Engineering } \\
\text { and Emerging } \\
\text { Technology }\end{array}$ & $\begin{array}{l}\text { Pengoperasian } \\
\text { Layanan } \\
\text { Domain pada } \\
\text { Instansi } \\
\text { Teknologi } \\
\text { Informasi dan } \\
\text { Komunikasi }\end{array}$ & ITIL v.3 & $\begin{array}{lr}\text { Nilai } & \text { diperoleh } \\
\text { dengan } & \text { tingkat } \\
\text { kematangan } & 3.539 \\
\text { (proses } & \text { yang } \\
\text { ditetapkan). } & \\
\text { Diskominfo } & \text { Kota } \\
\text { Denpasar } & \text { sudah } \\
\text { memiliki proses TI } & \text { yang } \\
\text { dibakukan delah } \\
\text { lingkup organisasi } \\
\text { secara } \\
\text { keseluruhan, tetapi } \\
\text { tidak memiliki } \\
\text { standar rakt } \\
\text { yang pasti } & \text { [4]. }\end{array}$ \\
\hline 5. & $\begin{array}{l}\text { Mekhmonov } \\
\text { Sultonali } \\
\text { Umaralievich } \\
\text { dan }\end{array}$ & $\begin{array}{l}\text { Audit internal } \\
\text { di sektor } \\
\text { ekonomi } \\
\text { swasta. }\end{array}$ & $I I A$ & $\begin{array}{l}\text { Memperkenalkan } \\
\text { rencana dan } \\
\text { program audit } \\
\text { berbasis risiko ke }\end{array}$ \\
\hline
\end{tabular}




\begin{tabular}{|c|c|c|c|c|}
\hline & $\begin{array}{l}\text { Temirkhanova } \\
\text { Mutabar } \\
\text { Jurayevna, } \\
2020, \\
\text { Journal of } \\
\text { Media \& } \\
\text { Management }\end{array}$ & & & $\begin{array}{lr}\text { sistem } & \text { audit } \\
\text { internal nasional } \\
\text { yang mencakup } \\
\text { risiko utama, risiko } \\
\text { yang muncul, } \\
\text { risiko horizon, dan } \\
\text { kewajiban } \\
\text { peraturan, sejalan } \\
\text { dengan kerangka } \\
\text { kerja sesuai } \\
\text { standar dalam } \\
\text { manajemen risiko } \\
\text { dan pengendalian } \\
\text { internal } \\
\text { perusahaan }[5] .\end{array}$ \\
\hline 6. & $\begin{array}{l}\text { Chalifa } \\
\text { Chazar, } \\
2015, \\
\text { Jurnal } \\
\text { Informasi }\end{array}$ & $\begin{array}{l}\text { Manajemen } \\
\text { keamanan } \\
\text { sistem } \\
\text { informasi. }\end{array}$ & $\begin{array}{l}\text { ISO/IEC } \\
27000, \\
\text { ISO/IEC } \\
27001: 2005\end{array}$ & $\begin{array}{lr}\text { Seri } & \text { ISO/IEC } \\
27000 & \text { dapat } \\
\text { digunakan } & \text { sebagai } \\
\text { standar } & \text { untuk } \\
\text { pengelolaan } & \\
\text { keamanan } & \text { sistem } \\
\text { informasi. } & \\
\text { Penggunaan } & \text { seri } \\
\text { ISO/IEC } & \text { 27000 } \\
\text { dapat } & \text { berlaku } \\
\text { dinamis } & \text { sesuai } \\
\text { dengan } & \text { adanya } \\
\text { kebutuhan } & \text { yang } \\
\text { diperlukan } & \text { oleh } \\
\text { organisasi } & \\
\text { perusahaan } & \text { untuk } \\
\text { mewujudkan } & \\
\text { sasaran atau tujuan } \\
\text { bisnis [6]. }\end{array}$ \\
\hline
\end{tabular}

\subsection{Pembahasan}

ISACA menyediakan banyak alat dan sumber daya untuk para profesional auditor teknologi informasi. ISACA dapat bermitra bisnis dengan individu dan organisasi tertentu dalam kegiatan yang berguna untuk menumbuhkan kinerja perusahaan yang siap dalam menghadapi kondisi tenaga informasi dan keamanan siber. ISACA akan memberi bantauan kepada para pimpinan perusahaan tentang bagaimana cara mengatur dalam mengelola sistem digital saat ini. Salah satu panduan yang dikembangkan ISACA adalah kerangka kerja COBIT. 
COBIT 5 (versi terbaru) pada umumnya memiliki 5 prinsip dasar yaitu:

a. Memenuhi kebutuhan Stakeholder

Terdapat kegiatan usaha dari suatu organisasi perusahaan untuk menciptakan nilai lebih bagi para pemangku kepentingan dengan menjaga keselarasan dan keseimbangan antara hubungan manfaat, pengoptimalan risiko, dan pemanfaatan sumber daya.

b. Menutupi Perusahaan dari Ujung ke Ujung

Prinsip ini bermanfaat untuk menintegrasikan kegiatan audit teknoli informasi perusahaan.

c. Menerapkan Kerangka Kerja Terintegrasi Tunggal

Terdapat banyak paket kerangka kerja audit standar yang berkaitan dengan IT. Dari beberapa metode, masing-masing memberikan panduan pada subset dari kegiatan IT.

d. Mendukung Pendekatan Holistik

Adit tata kelola teknologi informasi dan manajemen perusahaan yang efektif dan efisien membutuhkan pendekatan holistic, dengan mempertimbangkan beberapa komponen yang saling berinteraksi.

e. Memisahkan Tata Kelola dari Manajemen

COBIT akan membuat perbedaan terhadap objek pengawasan yang cukup jelas antara tata kelola dan manajemen.

Selanjutnya, ada kerangka kerja COSO yang lebih sering digunakan untuk evaluasi Enterprise risk management (ERM) dalam mengatasi adanya risiko melalui tahapan pengenalan, melakukan evaluasi, dan meminimalkan biaya yang muncul akibat risiko, serta melihat kemungkinan kejadian potensial yang dapat menyebabkan kerugian. COSO memberikan penjelasan bahwa efektivitas ERM suatu organisasi harus dinilai dari empat tujuan berikut:

1. Strategi, merupakan tujuan utama yang sejalan dan mendukung adanya misi organisasi, 
2. Operasi, yaitu berkaitan dengan pemanfaatan adanya sumber daya yang tepat guna dan tentu hemat biaya.

3. Pelaporan, yang kegiatan memberikan hasil pemaparan audit dan evaluasi.

4. Kepatuhan, meliputi taat terhadap hukum dan peraturan yang masih berlaku.

Selanjutnya, pada metode Audit Teknologi Informasi ITIL V.3 memberikan gambaran bahwa teknologi informasi dimanfaatkan sebagai penggunaan untuk melakukan penyimpanan, kegiatan komunikasi atau pemrosesan informasi. Kerangka kerja ITIL memiliki Maturity Model sebagai berikut:

a. Level 0: proses tidak selesai

Pada tahap ini perusahaan atau organisasi tidak mengimplementasikan proses TI yang seharusnya ada dalam artian belum berhasil mewujudkan tujuan proses TI.

b. Level 1: proses yang dilakukan

Pada tahap ini perusahaan atau organisasi telah sedikit berhasil mengimplementasikan proses TI dan tujuan proses TI benar-benar tercapai.

c. Level 2: proses yang dikelola

Pada tahap ini perusahaan atau organisasi dalam mengimplementasikan proses TI dan mencapai tujuannya dikelola dengan baik. Jadi ada lebih banyak suara untuk implementasi dan pencapaian yang dilakukan dengan manajemen yang tepat. Manajemen di sini berarti penerapannya dengan tahapan perencanaan, evaluasi dan penyesuaian untuk kegiatan lanjutan yang lebih baik lagi.

d. Level 3: proses yang ditetapkan

Pada tahap ini perusahaan atau organisasi memiliki proses TI yang telah baku dan dilakukan proses standarisasi dalam keseluruhan organisasi. Ini berarti bahwa proses TI standar yang ada berlaku di seluruh ruang lingkup organisasi. 
e. Level 4: proses yang dapat diprediksi

Pada tahap ini perusahaan atau organisasi telah menjalankan proses TI yang tepat dalam batas-batas yang jelas, seperti batas waktu. Batasan ini dihasilkan dari pengukuran yang telah dilakukan selama pelaksanaan proses TI sebelumnya.

f. Level 5: proses optimalisasi

Pada tahap ini perusahaan atau organisasi telah melakukan banyak inovasi dan peningkatan berkelanjutan agar proses implementasi TI menjadi optimal untuk meningkatkan kemampuannya.

Kemudian, pada proses audit internal yang terstruktur di sekitar analisis dan pelaporan terbagi pada beberapa area fokus berikut ini:

1. Tinjauan operasi untuk memastikan audit teknologi informasi apakah hasilnya konsisten dan stabil dengan apa yang menjadi tujuan dan sasaran perusahaan yang telah ditetapkan dan apakah operasi dilaksanakan sesuai rencana.

2. Keandalan dan integritas dalam informasi keuangan, kegiatan operasi dan sarana yang digunakan untuk menjalankan proses identifikasi, kegiatan mengukur, mengklasifikasikan, dan terakhir melaporkan informasi tersebut.

3. Tinjauan sistem yang ditetapkan untuk memastikan kepatuhan dengan kebijakan, rencana, prosedur, undang-undang, dan peraturan-peraturan lainnya yang dapat memiliki dampak signifikan pada operasi dan laporan, dan menentukan apakah organisasi mematuhi

4. Tinjauan sarana melindungi aset dan, jika perlu, memverifikasi keberadaan aset tersebut.

5. Menilai ekonomi dan efisiensi yang digunakan sumber daya.

Terakhir, kerangka kerja ISO/IEC 27000 digunakan untuk audit teknologi informasi di semua jenis organisasi baik level organisasi pemerintahan, organisasi komersial, maupun pada organisasi nonkomersial. 


\section{KESIMPULAN}

Pada ulasan yang telah kita lakukan kali ini memberikan informasi baru dan wawasan mengenai tahapan-tahapan yang ada dari beberapa penerapan kerangka kerja audit teknologi informasi yang terstandarisasi dan diakui oleh internasional. Penerapan audit tata kelola teknologi informasi harus dimulai ketika suatu sistem informasi sedang dibangun dan mulai dijalankan secara sistematis. Dengan adanya audit TI yang baik, maka diharapkan perusahaan dapat meningkatkan nilai kinerja dan produktifitas perusahaan serta dapat memprediksi risiko-risiko yang mungkin saja bisa muncul. 


\section{DAFTAR PUSTAKA}

[1] Labib, N. (2019). Mengenal Information Systems Audit and Control Association (ISACA). Bandar Lampung: Fakultas Komputer Universitas Mitra Indonesia. doi:10.31219/osf.io/m93u 8

[2] Suryono, R. R., Darwis, D., \& Gunawan, S. I. (2018). AUDIT TATA KELOLA TEKNOLOGI INFORMASI MENGGUNAKAN FRAMEWORK COBIT 5 (STUDI KASUS: BALAI BESAR PERIKANAN BUDIDAYA LAUT LAMPUNG). Jurnal TEKNOINFO, 12(1), 16-22.

[3] Pamungkas, A. (2017). Pengaruh Penerapan Enterprise Risk Management (COSO) Terhadap Nilai Perusahaan: Studi Empiris pada Perusahaan Manufaktur yang Terdaftar di BEI. Jurnal Akuntansi Maranatha, Program Studi Akuntansi, Fakultas Ekonomi, Universitas Kristen Maranatha, 11(1), 1221.

[4] Wijaya, A. P., Widiadnyana, P., \& Swamardika, I. B. (2016). Audit of Information Technology using ITIL V.3 Domain Service Operation on Communications and Information Technology Agency. International Journal of Engineering and Emerging Technology, 1(1), 11-14.

[5] Umaralievich, M. S., \& Jurayevna, T. M. (2020). The Role of the Internal Audit Based International Internal Audit Standards in Uzbekistan. Journal of Media \& Management, 2(1), 1-5.

[6] Chazar, C. (2015). STANDAR MANAJEMEN KEAMANAN SISTEM INFORMASI BERBASIS ISO/IEC 27001:2005. Jurnal Informasi, VII (2), 4857. 